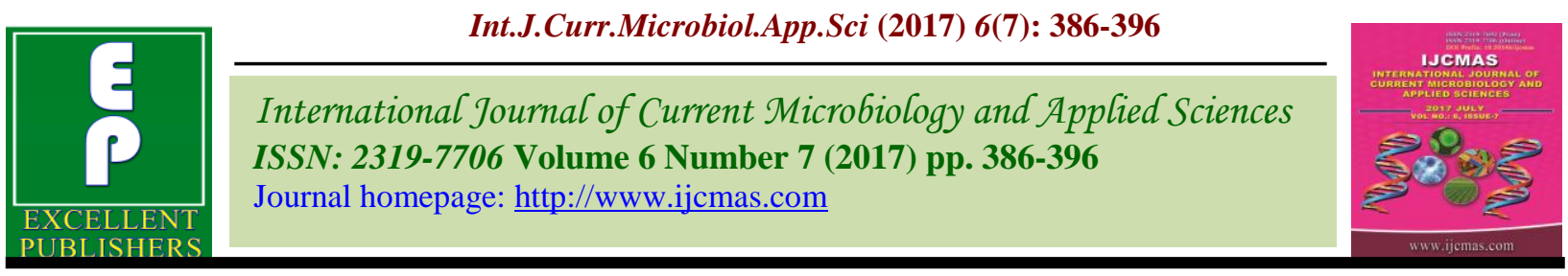

Original Research Article

https://doi.org/10.20546/ijcmas.2017.607.046

\title{
Characterization and Antibiogram of Klebsiella Isolated from Clinical Samples
}

\author{
A. Asha*, Vimal Kumar Karnaker and Rekha Rai \\ Department of Microbiology, KS Hegde Medical Academy, Deralakatte, \\ Mangalore-575018, Karnataka, India \\ *Corresponding author
}

\begin{tabular}{|c|c|}
\hline & A B S T R A C T \\
\hline $\begin{array}{l}\text { Ke y w o r d s } \\
\text { Industrialization, } \\
\text { Industrial affected } \\
\text { Soil, Heavy } \\
\text { metals, Metal } \\
\text { toxicity, Di - acid } \\
\text { mixture. }\end{array}$ & $\begin{array}{l}\text { Klebsiella spp exhibits an increased antimicrobial resistance by producing Extended } \\
\text { Spectrum Beta Lactamases (ESBL) and Carbapenamases. Studying their resistance pattern } \\
\text { will help in appropriate use of antibiotics and infection control. Aim of the study is to } \\
\text { characterize Klebsiella, to determine their antibiogram by disc diffusion, phenotypic } \\
\text { detection of ESBL and carbapenemase. The study was conducted in the Department of } \\
\text { Microbiology, K.S. Hegde Medical Academy, on the isolates of Klebsiella from samples } \\
\text { of exudates, blood, CSF, body fluids, sputum and urine from October } 2014 \text { to April } 2016 . \\
\text { Klebsiella were characterized and antibiotic susceptibility testing, phenotypic tests for }\end{array}$ \\
\hline Article Info & ESBL and Carbapenemase production were done as per CLSI guidelines. Amongst 509 \\
\hline $\begin{array}{l}\text { Accepted: } \\
\text { 04 June } 2017 \\
\text { Available Online: } \\
\text { 10 July } 2017\end{array}$ & $\begin{array}{l}\text { Klebsiella isolates, } 93.3 \% \text { were Klebsiella pneumoniae and } 6.6 \% \text { were Klebsiella oxytoca. } \\
\text { Maximum susceptibility was to Meropenem }(76.6 \%) \text {, Imipenem }(75.83 \%) \text {. Maximum } \\
\text { resistance }(68.5 \%-69.5 \%) \text { was to the third generation Cephalosporins. Multi drug } \\
\text { resistant Klebsiella comprised } 28 \% \text {, ESBL producers were } 53.83 \% \text { and } 12.3 \% \text { were } \\
\text { Carbapenamase producers. Monitoring the ESBL and Carbapenamase production, for an } \\
\text { effective antibiotic policy prevents MDR Klebsiella and isolation by strict infection control } \\
\text { prevents outbreaks. }\end{array}$ \\
\hline
\end{tabular}

\section{Introduction}

The genus Klebsiella contains Gram negative, capsulated, non-motile bacilli, belonging to the Enterobacteriaceae family (Mackie, 1999). There are five species under this genus, Klebsiella pneumoniae, Klebsiella oxytoca, Klebsiella planticola, Klebsiella terrigena, and Klebsiella ornithinolytica. Amongst them, the most common opportunistic and nosocomial pathogen is Klebsiella pneumoniae causing pneumonia, pyogenic infections, meningitis, urinary tract infections (UTI) and rarely diarrhoea and attack immunocompromised, hospitalized individuals associated with diabetes mellitus, chronic pulmonary, cardiac, renal and neoplastic diseases (Orhue et al.,2015)

They can be found in the gastrointestinal tract of humans and animals and have a wide distribution in nature (Koneman, 2006) They are exhibiting an increase in antimicrobial resistance making it essential for the identification of resistant bacteria. This in turn helps to tailor the empirical therapy as there will be no new antibiotics in the near future (Bora et al., 2014). 
This resistance of Klebsiella spp is mainly due to the production of extended spectrum beta lactamases (ESBLs), which are enzymes that hydrolyse and inactivate betalactam drugs like penicillin, third generation cephalosporins, aztreonam. Recent reports record ESBL producing Klebsiella spp being resistant to aminoglycosides, flouroquinolones, tetracycline, chloramphenicol, and sulfonamides (Asma et al., 2012).

A major risk factor for ESBL producing Klebsiella pneumoniae is the widespread use of third generation cephalosporins. Other risk factors which contribute to colonization and infection are arterial and central venous catheterization, prolonged stay in Intensive care unit (ICU), low birth weight in preterm infants, prior antibiotic use and mechanical ventilation (Gupta et al., 2003).

ESBLs are coded by transferable, conjugative plasmids which can lead to outbreaks (Shukla et al., 2004). These multi drug resistant (MDR) bacteria mostly do not respond to the available antibiotics. The drug of choice for ESBL producing pathogens are carbapenems, but the increase in use is leading to selection pressure and the emergence of carbapenem resistant organisms (Lee et al., 2006). It is a cause for concern as carbapenems are also the last line of treatment in multi-drug resistant Klebsiella pneumoniae infections (Pitout et al., 2015).

There is a global spread due to the acquisition of resistance through mobile genetic elements encoding carbapenamases. Carbapenamase producing Klebsiella pneumoniae (CPKP) is a major nosocomial pathogen among the carbapenamase producing enterobacteriaceae (CPE) (Tseng et al., 2015).

Carbapenem resistant Klebsiella pneumoniae is associated with high morbidity and mortality and the treatment options have been further narrowed down to polymyxins, which can be prevented by the judicious use of carbapenems (Kaur et al., 2016).

Hence studying the resistance pattern of these organisms will help in guiding the appropriate use of antibiotics and in designing the antibiotic policy for infection control programmes (Ravichitra et al., 2014) as the prospect of new antibiotics in near future is very less (Shweta et al., 2014).

This study aimed to characterize Klebsiella isolated from all clinical samples, determine their antibiogram by disc diffusion method and confirm the presence of ESBL, Carbapenemase in multidrug resistant strains by phenotypic methods and the results will help in instituting infection control against these organisms.

\section{Materials and Methods}

The study was conducted in the Department of Microbiology, K.S. Hegde Medical Academy, on the isolates of Klebsiella isolated from samples of exudates, blood, CSF, body fluids, sputum and urine sent to the Department of Microbiology from October 2014 to April 2016.

\section{Methods of processing}

Mucoid, lactose fermenting, colonies on Mac Conkey's agar and greyish, mucoid colonies on blood agar after overnight incubation at $37^{\circ} \mathrm{C}$ were subjected to standard Biochemical tests like indole production, citrate utilization, triple sugar iron, urease production, mannitol motility, sugar fermentation, aminoacid decarboxylation, methyl red and VogesProskauer (Table 1).

Antibiotic susceptibility testing was done on Muller Hinton agar using Kirby Bauer disc diffusion method, according to the CLSI guidelines for the following antibiotics : 
Ampicillin $10 \mathrm{mcg}$, Piperacillin $100 \mathrm{mcg}$, Piperacillin/tazobactam 100/10 mcg, Cefepime $30 \mathrm{mcg}$, Cefotaxime $30 \mathrm{mcg}$, Ceftriaxone $30 \mathrm{mcg}$, Cefoxitin $30 \mathrm{mcg}$, Ceftazidime $30 \mathrm{mcg}$, Imipenem $10 \mathrm{mcg}$, Meropenem $10 \mathrm{mcg}$, Gentamycin $10 \mathrm{mcg}$, Tobramycin $10 \mathrm{mcg}$, Amikacin $30 \mathrm{mcg}$, Tetracycline $30 \mathrm{mcg}$, Ciprofloxacin $5 \mathrm{mcg}$, Gatifloxacin $5 \mathrm{mcg}$, Nalidixic acid $30 \mathrm{mcg}$, Cotrimoxazole $\quad 1.25 / 23.75 \quad \mathrm{mcg}$, chloramphenicol $30 \mathrm{mcg}$, Nitrofurantoin 300 mcg.

\section{Detection of Extended Spectrum Beta Lactamase (ESBL) production}

\section{Screening test}

Initial screen test was done by disk diffusion method on Mueller Hinton Agar (MHA) using Ceftazidime $30 \mu \mathrm{g}$ and Cefotaxime 30 $\mu \mathrm{g}$ disks. Ceftazidime zone of $\leq 22 \mathrm{~mm}$ and Cefotaxime zone of $\leq 27 \mathrm{~mm}$ were considered to be positive for ESBL screening._Quality control strain: Klebsiella pneumoniae ATCC 700603

\section{Phenotypic confirmatory test}

Confirmatory test for ESBL production was carried out by Disk Diffusion method using Ceftazidime $30 \mu \mathrm{g}$, Ceftazidime-clavulanate 30/10 $\mu \mathrm{g}$, Cefotaxime $30 \mu \mathrm{g}$, Cefotaximeclavulanate $30 / 10 \mu \mathrm{g}$. A $\geq 5 \mathrm{~mm}$ increase in a zone diameter for either antimicrobial agent tested in combination with clavulanate v/s the zone diameter of the agent when tested alone was confirmed for ESBL production.

\section{Amp C betalactamase screening}

Screen test was done by disk diffusion method on Mueller Hinton Agar (MHA) and Cefoxitin $30 \mu \mathrm{g}$ disk was placed. Cefoxitin zone of $<18 \mathrm{~mm}$ was considered to be positive for AmpC beta lactamase screening.

\section{Carbapenamase screening}

Screening is positive for those isolates which are either intermediate or resistant to any one of the carbapenems using Ertapenem $10 \mu \mathrm{g}$ or Meropenem $10 \mu \mathrm{g}$ or Imipenem $10 \mu \mathrm{g}$ disk. Ertapenem zone of $19-21 \mathrm{~mm}$ or $\leq 18 \mathrm{~mm}$ and Imipenem, Meropenem zone of 20-22 mm or $\leq 19 \mathrm{~mm}$ were considered to be positive for Carbapenamase screening.

\section{Carbapenamase confirmation}

By the modified Hodge test using meropenem $10 \mu \mathrm{g}$. Enhanced growth = positive for carbapenemase production. No enhanced growth $=$ negative for carbapenemase production. Statistical analysis was done using SPSS software version 21.0.

\section{Results and Discussion}

There was a total of 509, non-repeat isolates of Klebsiella from October 2014 to April 2016. The maximum isolates, (20.2\%) were from 41-50 years age group, followed by $18.9 \%$ from 21-20 year's age group and the isolates were recovered more from males $(61 \%)$.

Maximum isolates were from Exudates $(48 \%)$, followed by urine samples $(28 \%)$ and they were from samples from General Medicine (48.3\%), followed by General Surgery (19.6\%). All were lactose and dextrose fermenters, positive for lysine and negative for arginine, ornithine decarboxylation.

There were totally 475 (93.3\%) Klebsiella pneumoniae isolates, out of which 438 $(86.05 \%)$ were subspecies aerogenes, 36 $(7.07 \%)$ were subspecies pneumoniae, 1 $(0.19 \%)$ was subspecies ozaenae and 34 $(6.67 \%)$ Klebsiella oxytoca isolates (Table 2). 
In the resistance pattern, there was $100 \%$ resistance to Ampicillin, 32.61\% resistance to Piperacillin/Tazobactam, $66.9 \%$ were resistant to Cefepime, $68.5 \%$ were resistant to Ceftazidime, $29.4 \%$ were resistant to Cefoxitin, $21.8 \%$ were resistant to both Imipenem and Meropenem, 26.7\% were resistant to Amikacin, 37.5\% were resistant to Gatifloxacin, $35.7 \%$ and $34.1 \%$ were resistant to Tetracycline and Chloramphenicol respectively, while there was $39.4 \%$ resistance to Cotrimoxazole (Table 3 and Fig. $1)$.

On the whole there were $143(28.0 \%)$ isolates that were multi drug resistant (MDR).

Amongst the sensitivity pattern, there was $64.05 \%$ sensitivity to Piperacillin/Tazobactam, $30.26 \%$ were sensitive to cefepime, $28.2 \%$ were sensitive to Ceftazidime, $66.99 \%$ were sensitive to Cefoxitin, $75.8 \%$ and $76.6 \%$ were sensitive to Imipenem and Meropenem respectively, $69.74 \%$ were sensitive to Amikacin, $60.3 \%$ were sensitive to Gatifloxacin, $60.9 \%$ and $62.6 \%$ were sensitive to Tetracycline and chloramphenicol respectively while $56.9 \%$ were sensitive to cotrimoxazole.

Out of 509 isolates, 356 were positive for ESBL production by screening method (Table 4 and Fig. 2).

Out of 356 isolates positive for ESBL by screening method, there were 274 (76.9\%) positive and $11(3.08 \%)$ negative by the confirmatory method, while 71 (19.9\%) isolates yielded no detectable results with any potentiation zones (Table 5).

Out of 475 Klebsiella pneumoniae, 259 $(54.52 \%)$ were ESBL producers and out of 34 Klebsiella oxytoca isolates, 15 (44.11\%) were ESBL producers. Out of 509 isolates, $259(50.88 \%)$ were Klebsiella pneumoniae producing ESBL while 15 (2.94\%) were Klebsiella oxytoca producing ESBL (Fig. 3).

There were $130(25.5 \%)$ isolates which screened positive for AmpC beta lactamase production, out of which $125(96.15 \%)$ were Klebsiella pneumoniae and 5 (3.84\%) were Klebsiella oxytoca isolates.

Out of 509 isolates 119 (23.4\%) were positive on screening for Carbapenamase production (Table 6).

Out of the 119 isolates positive for carbapenamase production by screening, 63 $(52.9 \%)$ were positive and $56(47.1 \%)$ were negative for carbapenamse production by the modified Hodge test, 62 were Klebsiella pneumoniae and 1 remaining isolate was Klebsiella oxytoca. Out of the 509 isolates, there were $63 \quad(12.3 \%)$ Carbapenamase producers those are identified by Modified Hodge test (Table 7 and Figs. 4 and 5).

Klebsiella species, as a multidrug resistant, nosocomial pathogen is contributing to significant morbidity and mortality. It threatens the available treatment options and due to its high clinical prevalence, has become a cause for global concern.

In this study, we have over the duration of 18 months isolated a high number of 509 Klebsiella species (non-repeat) from various clinical specimens, as compared to the 100 Klebsiella species isolated over 22 months by Namratha et al., (2015), 120 Klebsiella species isolated over the duration of 1 year by Chakraborthy et al., (2016) and the 116 non repeated isolates, over 5 months reported by Asmaa et al., (2012) and more commonly isolated in the 41-50 years age group, slightly lower than the 45-60 years age group found in the study by Namratha et al., (2015) and Chakraborthy et al., (2016). 
Majority of the Klebsiella spp were isolated From exudates $(48 \%)$ followed by urine (28\%) which was in agreement with the studies by Namratha et al., (2015), Biradar et al., (2015) while in the studies by Asmaa et al., (2012) and Chakraborty et al., (2016). As far as Blood stream infections are concerned, $5 \%$ of the isolates were from Blood, Slightly lower than the $7 \%$ reported by Biradar et al., (2015). This predominance of Klebsiella isolates occurring in exudates and urine corroborates the suggestion that they tend to cause more of wound infection and urinary tract infection, and the nature of these infections can be both nosocomial and community acquired. Studying the nature of the pathogen, along with its antibiogram from a particular word and its distribution among the others, helps in concentrating good infection control practices where needed.

The prevalence of Klebsiella pneumoniae was higher, in this study, 93\%, than the prevalence of Klebsiella oxytoca which was 7\%. Other studies too have reported higher prevalence of Klebsiella pneumoniae than Klebsiella oxytoca with $21.6 \%$ of Klebsiella pneumoniae and $2.4 \%$ of Klebsiella oxytoca by Chakraborthy et al., (2016), $79 \%$ and $21 \%$ by Namratha et al., (2015), $89 \%$ and $11 \%$ by Biradar et al., (2015) and 65.5\%, 34.5\% by Asmaa et al., (2012).

Table.1 Key biochemical reaction results for speciation

\begin{tabular}{|c|c|c|c|c|}
\hline Indole & + & - & - & - \\
\hline Citrate & + & + & + & + \\
\hline MR & - & - & + & - \\
\hline VP & + & + & - & - \\
\hline Urease & + & + & + & - \\
\hline Identification & $\begin{array}{l}\text { Klebsiella } \\
\text { Oxytoca }\end{array}$ & $\begin{array}{l}\text { Klebsiella } \\
\text { pneumoniae } \\
\text { subsp aerogenes }\end{array}$ & $\begin{array}{l}\text { Klebsiella } \\
\text { pneumoniae } \\
\text { subsp } \\
\text { pneumoniae }\end{array}$ & $\begin{array}{l}\text { Klebsiella } \\
\text { pneumoniae } \\
\text { subsp } \\
\text { Ozaenae }\end{array}$ \\
\hline
\end{tabular}

$+=$ positive,$-=$ negative

Table.2 Characterization pattern

\begin{tabular}{|l|l|l|}
\hline Species & Number & Percentage (\%) \\
\hline $\begin{array}{l}\text { Klebsiella pneumoniae or Klebsiella pneumoniae } \\
\text { subsp aerogenes }\end{array}$ & 438 & 86.05 \\
\hline Klebsiella pneumoniae subsp pneumoniae & 36 & 7.07 \\
\hline Klebsiella pneumoniae subsp ozaenae & 1 & 0.19 \\
\hline Klebsiella oxytoca & 34 & 6.67 \\
\hline
\end{tabular}


Table.3 Antibiotic susceptibility pattern

\begin{tabular}{|c|c|c|c|c|c|c|}
\hline & \multicolumn{3}{|c|}{ COUNTS } & \multicolumn{3}{|c|}{ PERCENTAGES } \\
\hline & RESISTANT & INTERMEDIATE & SENSITIVE & RESISTANT & INTERMEDIATE & SENSITIVE \\
\hline AST: Ampicillin & 509 & 0 & 0 & $100.00 \%$ & $0.00 \%$ & $0.00 \%$ \\
\hline Piperacillin & 194 & 21 & 294 & $38.11 \%$ & $4.13 \%$ & $57.76 \%$ \\
\hline Piperacillin/Tazobactam & 166 & 17 & 326 & $32.61 \%$ & $3.34 \%$ & $64.05 \%$ \\
\hline Cefepime & 341 & 14 & 154 & $66.99 \%$ & $2.75 \%$ & $30.26 \%$ \\
\hline Cefotaxime & 354 & 7 & 148 & $69.55 \%$ & $1.38 \%$ & $29.08 \%$ \\
\hline Ceftriaxone & 351 & 7 & 151 & $68.96 \%$ & $1.38 \%$ & $29.67 \%$ \\
\hline Ceftazidime & 349 & 16 & 144 & $68.57 \%$ & $3.14 \%$ & $28.29 \%$ \\
\hline Cefoxitin & 150 & 18 & 341 & $29.47 \%$ & $3.54 \%$ & $66.99 \%$ \\
\hline Imipenem & 111 & 12 & 386 & $21.81 \%$ & $2.36 \%$ & $75.83 \%$ \\
\hline Meropenem & 111 & 8 & 390 & $21.81 \%$ & $1.57 \%$ & $76.62 \%$ \\
\hline Amikacin & 136 & 18 & 355 & $26.72 \%$ & $3.54 \%$ & $69.74 \%$ \\
\hline Gentamicin & 165 & 20 & 324 & $32.42 \%$ & $3.93 \%$ & $63.65 \%$ \\
\hline Tobramycin & 115 & 17 & 377 & $22.59 \%$ & $3.34 \%$ & $74.07 \%$ \\
\hline Ciprofloxacin & 204 & 13 & 292 & $40.08 \%$ & $2.55 \%$ & $57.37 \%$ \\
\hline Gatifloxacin & 191 & 11 & 307 & $37.52 \%$ & $2.16 \%$ & $60.31 \%$ \\
\hline Tetracycline & 182 & 17 & 310 & $35.76 \%$ & $3.34 \%$ & $60.90 \%$ \\
\hline Chloramphenicol & 174 & 16 & 319 & $34.18 \%$ & $3.14 \%$ & $62.67 \%$ \\
\hline Nitrofurantoin & 227 & 26 & 256 & $44.60 \%$ & $5.11 \%$ & $50.29 \%$ \\
\hline Nalidixic acid & 222 & 17 & 270 & $43.61 \%$ & $3.34 \%$ & $53.05 \%$ \\
\hline Cotrimoxazole & 201 & 18 & 290 & $39.49 \%$ & $3.54 \%$ & $56.97 \%$ \\
\hline
\end{tabular}


Table.4 ESBL screening

\begin{tabular}{|l|l|l|l|}
\hline Test & $\begin{array}{l}\text { Positive } \\
\text { Number }(\%)\end{array}$ & $\begin{array}{l}\text { Negative } \\
\text { Number }(\%)\end{array}$ & $\begin{array}{l}\text { Total } \\
\text { Number }\end{array}$ \\
\hline ESBL screening & $356(69.95)$ & $153(30.1)$ & 509 \\
\hline
\end{tabular}

Table.5 ESBL confirmation

\begin{tabular}{|l|l|l|l|l|}
\hline Test & $\begin{array}{l}\text { Positive } \\
\text { Number (\%) }\end{array}$ & $\begin{array}{l}\text { Negative } \\
\text { Number }(\%)\end{array}$ & $\begin{array}{l}\text { Not detected } \\
\text { Number }(\%)\end{array}$ & $\begin{array}{l}\text { Total } \\
\text { Number }(\%)\end{array}$ \\
\hline $\begin{array}{l}\text { ESBL } \\
\text { confirmation }\end{array}$ & $274(76.9)$ & $11(3.08)$ & $71(19.9)$ & $356(100)$ \\
\hline
\end{tabular}

Table.6 Carbapenamase production screening

\begin{tabular}{|l|r|r|}
\hline & Carbapenamase screening & Percentage \\
\hline NEG & 390 & 76.6 \\
\hline POS & 119 & 23.4 \\
\hline Total & 509 & 100 \\
\hline
\end{tabular}

Table.7 Carbapenamase production confirmation, modified Hodge test

\begin{tabular}{|l|l|l|l|}
\hline Test & $\begin{array}{l}\text { Positive } \\
\text { Number (\%) }\end{array}$ & $\begin{array}{l}\text { Negative } \\
\text { Number }(\%)\end{array}$ & $\begin{array}{l}\text { Total } \\
\text { Number }(\%)\end{array}$ \\
\hline Modified Hodge test & $63(52.9)$ & $56(47.1 \%)$ & $119(100 \%)$ \\
\hline
\end{tabular}

Fig.1 Antibiotic susceptibility pattern

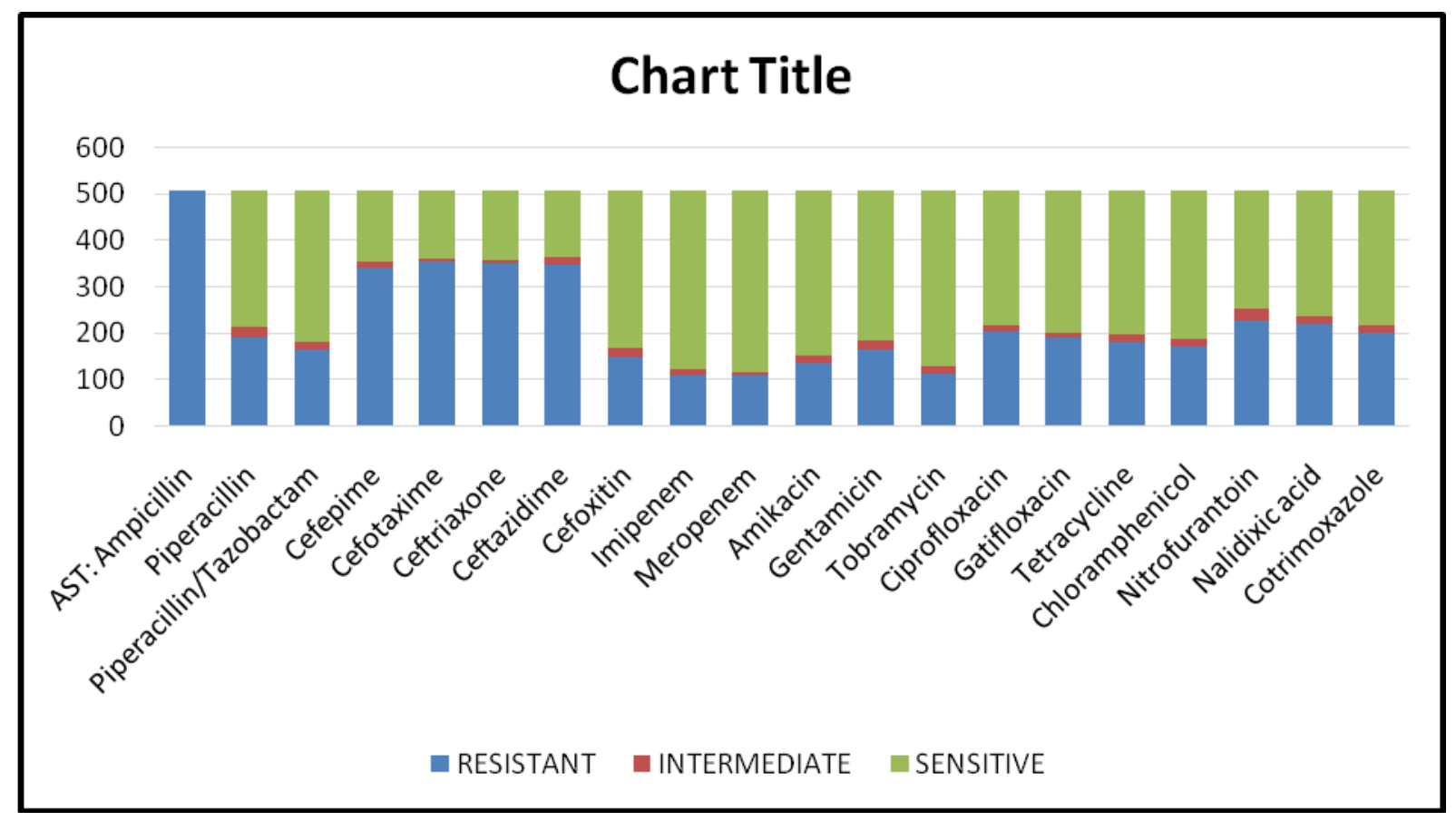


Fig.2 ESBL producers and non-producers

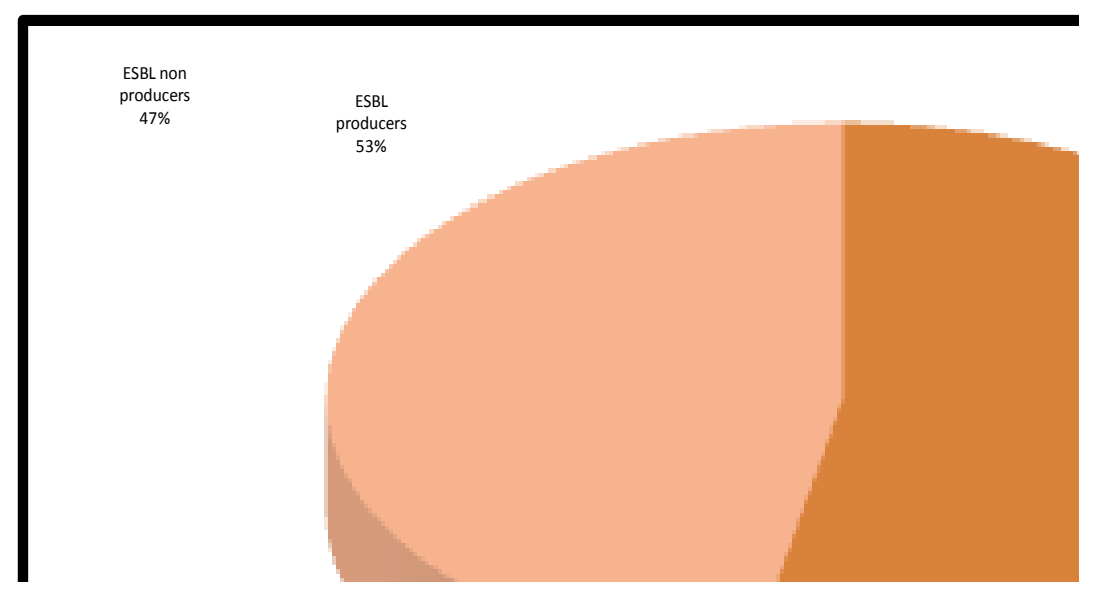

Fig.3 ESBL producers and non-producers among $K$. pneumoniae and K. oxytoca

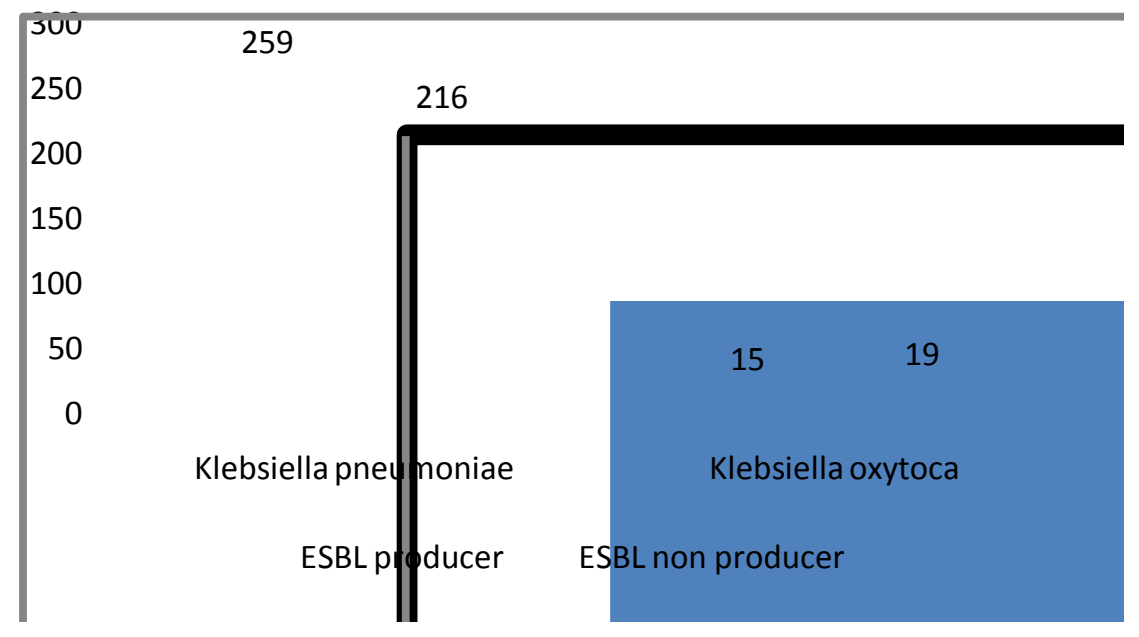

Fig.4 Modified Hodge test

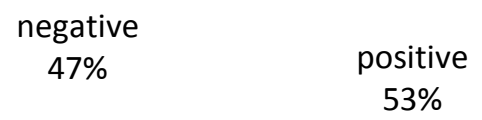


Fig.5 Carbapenamase production

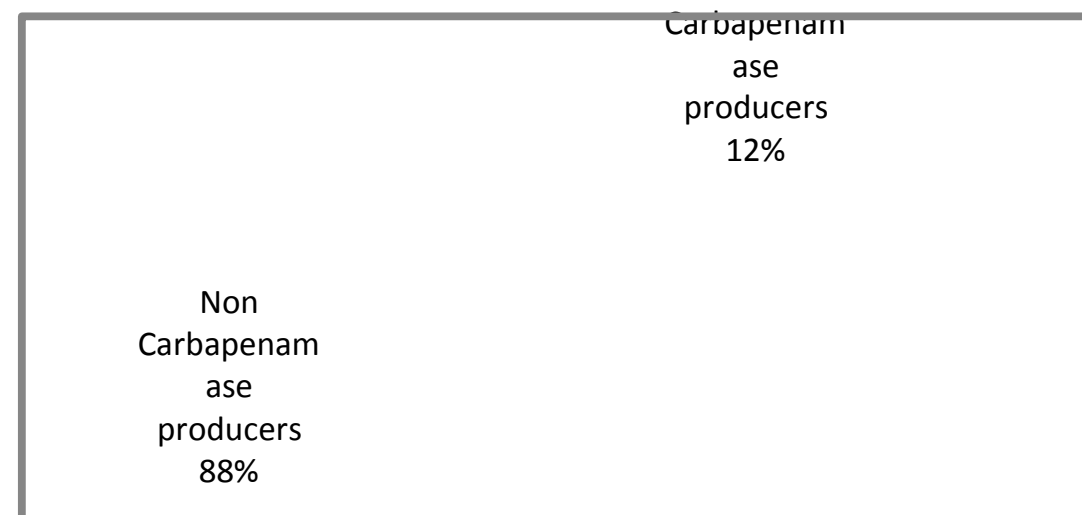

Klebsiella pneumoniae was further subspeciated, with $36(7.07 \%)$ of Klebsiella pneumoniae sub species pneumoniae 438 (86.05\%) of Klebsiella pneumoniae subsp aerogenes and 1 Klebsiella pneumoniae subsp ozaenae.

The necessity to identify upto the species level helps in understanding the pathogenicity, as there are, for instance high rate of catheter tip colonization by Klebsiella oxytoca (Namratha et al., 2015). For example, Lowe et al., (2012) have reported an outbreak of Klebsiella oxytoca infections due to contaminated hand washing sinks, and Joainig et al., (2012), have studied the cytotoxic effects of Klebsiella oxytoca in Antibiotic associated hemorrhagic colitis (Gupta et al., 2012).

In this study, in terms of sensitivity, the maximum sensitivity was to Carbapenems, $76.6 \%$ to Meropenem followed by $75.8 \%$ to Imipenem. In terms of resistance, apart from Ampicillin, maximum resistance was observed to the $3^{\text {rd }}$ generation cephalosporins $(68.5 \%$ to $69.5 \%$ ). In a study by Biradar et al., (2015), also maximum susceptibility was to Imipinem, although it was $100 \%$ and maximum resistance (50\%-70\%) was observed to third generation Cephalosporins. The differences in the susceptibility pattern between this study and others suggest the nature of multiple antibiotic resistance among Klebsiella spp. which may be acquired through, MDR plasmids. In this study, we report $28 \%$ of the isolates as MDR, which is lower, compared to 55\% MDR observed by Chakraborthy et al., (2016).

These MDR organisms cause serious infections with limited antibiotics available to treat them. Continuous antibiogram evaluation is necessary to design a safe and successful empiric treatment.

The ESBL confirmation by double disk synergy test (DDST) as per CLSI guidelines, has in this study detected $53.83 \%$ ESBL producers, higher than Chakraborthy et al., (2016) who reported 45\%, Asmaa et al., (2012), who reported 16.4\% and Biradar et al., (2015) who reported 24\% ESBL producers.

There were 71 isolates, in which the result could not be detected, with no potentiation zone around Clavulanic acid. This may be due to Amp C betalactamase production which inhibits the inhibitor action of Clavulanic acid (Biradar et al., 2015). In this study, ESBL producing Klebsiella pneumoniae $(50.88 \%)$ was similar to 50\% ESBL producing Klebsiella pneumoniae reported by Chakraborty et al., (2016), while ESBL producing Klebsiella oxytoca were only $2.94 \%$ as compared to the $25 \%$ by Chakraborthy et al., (2016). In the study by Asmaa et al., (2012), ESBL producers among Klebsiella pneumoniae (11.2\%) were more than for Klebsiella oxytoca (5.2\%). The prevalence of ESBL producers vary from one region to the 
other due to the differences in the infection control practices, extensive, inappropriate use of new extended spectrum antibiotics, antibiotic policy, carriage rate among hospital staff.

In this study, $119 \quad(23.4 \%)$ isolates intermediate/resistant to Meropenem, screened positive for potential Carbapenamase production. We reported Modified Hodge Test positive for 63 isolates (12.3\%) as Carbapenamase producers in this study, slightly higher when compared to $11.88 \%$ Carbapenamase producers as reported by Bora et al., 2014. In a study by Mona (2016) only $1 / 141(0.7 \%)$ was a Carbapenamase producer. In this study modified Hodge test has identified $63(52.9 \%)$ as Carbapenamase producers out of the 110 Carbapenamase resistant isolates, which is lower when compared to the detection of $88.14 \%$ of Carbapenem resistant isolates in a study of Fattouch et al., (2015).

The Carbapenamase resistance in isolates which were negative by Modified Hodge test could be due to impermeability by Porin loss, or over production of ESBL or Amp C beta lactamase enzyme. Many studies have reported a low sensitivity and specificity for the Modified Hodge test. This could be because this test does not differentiate between class A and class B of Caerbapenamases, but only recognizes Carbapenamase enzyme activity (Fattouch et al., 2015).

MHT positive results can occur in Carbapenem resistant organisms which do not produce Carbapenamase and are not positive for all types of Carbapenamase producing organisms (CLSI, 2013). None the less, it's a simple, easy, cost effective method to detect Carbapenamase production.

\section{Acknowledgement}

I express my deep gratitude to my respected teacher and guide, Dr. Vimal Kumar Karnaker, Professor, Dr. Rekha Rai, Professor and Head, Department of Microbiology, K.S. Hegde Medical Academy, for their constant guide and encouragement and to Dr. Satheesh Kumar Bhandary B, Dean, K.S. Hegde Medical Academy for the approval of this study. I am thankful to my teachers, colleagues all the nonteaching staff in the department of Microbiology for their kind support.

\section{References}

Al-Gerir AZ. Detection of extended spectrum beta-lactamases and antibiogram profile of Klebsiella species. Annals of the College Mosul. 2012; 38(1):33-9.

Biradar S, Roopa C. Isolation and Antibiogram of Klebsiella species from Various Clinical Specimens. Int. J. Curr. Microbiol. App. Sci. 2015; 4(9):991-5.

Bora A, Solanki A, Khatri PK, Parihar RS, Chandora A. Detection of Carbapenemase in Escherichia and Klebsiella from clinical samples of OPD and IPD patients in tertiary care hospital, Jodhpur, Western Rajasthan, India. Int. J. Curr. Microbiol. App. Sci. 2014; 3(3):866-87.

Chakraborty S, Mohsina K, Sarker PK, Alam MD, Karim M, Sayem SM. Prevalence, antibiotic susceptibility profiles and ESBL production in Klebsiella pneumoniae and Klebsiella oxytoca among hospitalized patients. Periodicum biologorum. 2016; 118(1):53-8.

Clinical and Laboratory Standards Institute. Performance standards for antimicrobial susceptibility testing. CLSI document Wayne, PA, USA. 2013; M100-S21.

Fattouh M, El-din AN, Omar MA. Detection of Klebsiella pneumoniae Carbapenemase (KPC) Producing Gram Negative Superbugs: An Emerging Cause of Multidrug-Resistant Infections in General Surgery Department of Sohag University Hospital, Egypt. Int. J. Curr. Microbiol. App. Sci. 2015; 4(5):1-5.

Gupta A, Ampofo K, Rubenstein D, Saiman L. Extended spectrum $\beta$ lactamase-producing Klebsiella pneumoniae infections: a review of the literature. Journal of perinatology. 2003; 23(6):439-43.

Gupta V, Kumarasamy K, Gulati N, Garg R, Krishnan P, Chander J. AmpC $\beta$-lactamases 
in nosocomial isolates of Klebsiella pneumoniae from India. The Indian journal of medical research. 2012; 136(2):237.

Joainig MM, Gorkiewicz G, Leitner E, Weberhofer P, Zollner-Schwetz I, Lippe I, Feierl G, Krause R, Hinterleitner T, Zechner EL, Högenauer C. Cytotoxic effects of Klebsiella oxytoca strains isolated from patients with antibiotic-associated hemorrhagic colitis or other diseases caused by infections and from healthy subjects. Journal of clinical microbiology. 2010; 48(3):817-24.

Kaur J, Sheemar S, Chand K, Chopra S, Mahajan G. Outbreak of Carbapenemase-Producing Klebsiella pneumoniae Blood Stream Infections in Neonatal Intensive Care Unit. Int. J. Curr. Microbiol. App. Sci. 2016; 5(1): 727-33.

Lee $\mathrm{CH}$, Su LH, Tang YF, Liu JW. Treatment of ESBL-producing Klebsiella pneumoniae bacteraemia with carbapenems or flomoxef: a retrospective study and laboratory analysis of the isolates. Journal of Antimicrobial Chemotherapy. 2006; 58(5):1074-7.

Lowe C, Willey B, O'Shaughnessy A, Lee W, Lum M, Pike K, Larocque C, Dedier H, Dales L, Moore C, McGeer A. Outbreak of extended-spectrum $\beta$-lactamase-producing Klebsiella oxytoca infections associated with contaminated hand washing sinks. Emerg Infect Dis. 2012; 18(8):1242-7.

Mackie MC, McCartney JE. Practical Medical Microbiology: Eds. Collee JG, Fraser AG, Marnion BP Simmons A. Tests for identification of bacteria. 14th Edition. Churchill living stone publishers, UK. 1999.

Mona F Foad, 2016. Phenotypic Detection and Antimicrobial susceptibility Profile of ESBL, AmpC and Carbapenemase producing Gram-negative isolates from Outpatient clinic specimens. Int.J.Curr.Microbiol.App.Sci., (2016) 5(1):
740-752

Namratha KG, Sreeshma P, Subbannayya K, Dinesh PV, Champa H. Characterization and Antibiogram of Klebsiella spp. Isolated from Clinical Specimen in a Rural Teaching Hospital. Sch. J. App. Med. Sci. 2015; 3(2E):878-83.

Orhue PO, Aliu FR. Antibiogram and susceptibility of Klebsiella Spp isolated from different clinical specimens in health care centers in Etsako West local government area of EDO state, Nigeria. American Journal of Current Microbiology. 2015; 3(1):60-72.

Pitout JD, Nordmann P, Poirel L. Carbapenemaseproducing Klebsiella pneumoniae, a key pathogen set for global nosocomial dominance. Antimicrobial agents and chemotherapy. 2015; 59(10):5873-84.

Ravichitra KN, Prakash PH, Subbarayudu S, Rao US. Isolation and antibiotic sensitivity of Klebsiella pneumoniae from pus, sputum and urine samples. Int. J. Curr. Microbiol. App. Sci. 2014; 3(3):115-9.

Shukla I, Tiwari R, Agrawal M. Prevalence of extended spectrum-lactamase producing Klebsiella pneumoniae in a tertiary care hospital. Indian journal of medical microbiology. 2004; 22(2):87.

Shweta S, Hans C, Makhija LK, Mahajan RK. Prevalence of Extended Spectrum Blactamases and Metallo B-lactamases in bacterial isolates from burn patients. Int $\mathrm{J}$ Curr Microbiol App Sci. 2014; 3:529-35.

Tseng IL, Liu YM, Wang SJ, Yeh HY, Hsieh CL, Lu HL, Tseng YC, Mu JJ. Emergence of carbapenemase producing Klebsiella pneumonia and spread of KPC-2 and KPC17 in Taiwan: A nationwide study from 2011 to 2013. PloS one. 2015; 10(9): e0138471.

Winn WC. Koneman's color atlas and textbook of diagnostic microbiology. Koneman EW, editor. Lippincott Williams and wilkins; 2006.

\section{How to cite this article:}

Asha A. Vimal Kumar Karnaker and Rekha Rai. 2017. Characterization and Antibiogram of Klebsiella Isolated from Clinical Samples. Int.J.Curr.Microbiol.App.Sci. 6(7): 386-396. doi: https://doi.org/10.20546/ijcmas.2017.607.046 